\title{
SYNCHRONIZATION OF STOCK PRICE AND THE ROLE OF INSTITUTIONAL INVESTORS IN TEHRAN STOCK EXCHANGE Hussain Tayar $^{1 *}$, Mohsin Abbood Bandar ${ }^{2}$, Mohammed Jabbar Fashakh ${ }^{3}$ \\ ${ }^{1}$ Department of Financial Management, University of Karbala, Karbala, Iraq, ${ }^{2,3}$ Department of Accounting, University of Karbala, Karbala, Iraq. \\ Email: ${ }^{1 *}$ Hussain.tayar@yahoo.com, ${ }^{2}$ Mohsin.altaey1973@gmail.com, 33Abonabaa22@yahoo.com
}

\author{
Article History: Received on $21^{\text {st }}$ August 2019, Revised on $29^{\text {th }}$ September 2019, Published on $06^{\text {th }}$ November 2019
}

\begin{abstract}
Purpose of the study: The paper discusses the emergence of institutional investors as owners of capital in corporate governance are increasingly important. Institutional shareholders have the potential to influence management activities through an exchange of shares indirectly and directly respectively
\end{abstract}

Methodology: On the basis of this study, 42 companies between the years 1389 to 1393 were studied (data for 1388 also is intended to assess the results of 1389).

Results: The panel data model relationship between institutional investors with stock prices and the risk of concurrent fall in share prices was determined and it was found that institutional investors and significant negative correlation with share prices and the risk of concurrent fall in prices in the stock market Tehran.

Applications of this study: This research can be used for the universities, teachers, and students.

Novelty/Originality of this study: In this research, the model of Synchronization of Stock Price and the Role of Institutional Investors in the Tehran Stock Exchange is presented in a comprehensive and complete manner.

Keywords: institutional investors, synchronization of price, risk falling share prices and panel data.

\section{INTRODUCTION}

Attracting small capitals and domestic funds and directing them in line with industrial and manufacturing activities is necessary for achieving economic growth and development. In this regard, financial markets have emerged in two forms of the money market, funding the short term credits, and capital markets, funding the long term credits. Tehran Stock Exchange, as one of the components of the capital market, plays nowadays a major role in increasing the production of Iran and its development, so that it is stated that development of a country has a direct relationship with the prosperity of the stock exchange and the number of its shareholders. The proper organizing of this activity is under the responsibility of forces in the market. Undoubtedly, providing useful information and proper criteria for investors in the stock exchange, so that they can make the correct decision, can lead to persistent maintaining of the investors in the stock exchange by protecting their interests and preventing their loss. It can also lead to the growth of the economy by providing the conditions for the optimal allocation of limited economic resources to more profitable projects. In recent years, we have encountered with organizations and institutions called as institutional investors, including pension funds, banks, and insurance firms, holdings, investment firms, retirement funds, capital financing firms, and investment funds, and public agencies and institutions. Institutional investors play a major role in the efficiency of the capital market and their presence contributes to the efficiency and transparency of the capital market. Transparency of financial information has always been one of the most effective variables in determining the investment strategy in financial markets. It is also one of the most important concerns of investors and one of the most effective factors in determining the form of acquisition of stock firms by investors. Investors are always looking for transparent information to purchase a firm's stock. The source of information of the majority of capital market participants is financial reports issued by firms that are periodically provided to the public and are the basis for the decisions made by potential investors to purchase and sell and invest in the stock market. Moreover, separation of ownership and management in stock firms creates a potential conflict of interest between the managers and shareholders. This conflict of interest is referred as agency problem.

One of the results of the agency problem is the creation of information asymmetry between managers and shareholders and shareholders cannot observe the actions and activities of managers continuously (HassasYeganeh, 2005). By increasing the resources available for management, the number of beneficiaries also increases, leading to a greater conflict of interests. Managers, responsible for preparing financial statements, are always motivated to distort financial information to protect their interests. Earning management or manipulation is one of the managers' actions that lead to a lack of transparency in financial information (Belyaeva, 2014; Fetalieva, 2016; Ilyasov et al, 2017). Di George defined earnings management as a kind of artificial manipulation of earnings by management in order to access expected level of earnings for some particular decisions or goals and interests of managers. According to them, in fact, the main motivation for management of earnings is managing the views of investors in a business unit (HassasYeganeh, et al. 2008). In the earnings managing process, managers try to accumulate negative news inside the firm and not to disclose it. When this mass of accumulated negative news reaches its peak, it is released suddenly in the market, leading to stock price crashes. Therefore, it can be stated that the lack of transparency of financial information increases the risk of stock price crashes (Khanalievna et al, 2017; Shikhalieva, 2016; Antúnez, 2016). In addition, overconfidence of investors in the firm earnings depends on firm-specific 
information. When the relationship between market returns and firm returns (synchronization of price) is low, it indicates more firm-specific information. Firms that show low stock returns synchronization reflects the fact that prices are less dependent on market actions, as there is a greater amount of firm-specific information that market activists rely on it (; Moradi, 2007). Thus, the presence of institutional investors and their effective monitoring will reduce the conflict of interest and lack of transparency. Hence, this study aims to investigate the role of institutional investors and their relationship with synchronization of stick price and the risk of stocks price crash.

\section{RESEARCH LITERATURE}

Institutional investors, as a group of investors, play a key role in the economic development of the capital market due to availability to the great number of financial resources, and institutional investors are one of the external control mechanisms affecting corporate governance. The emergence of institutional investors as capital owners has increasing importance in corporate governance system. Institutional shareholders have the potential to influence the managers' activities through ownership indirectly and their stock exchange directly. The investors take effective measures to resolve the agency problems between managers and shareholders by presence in the firms. By increasing the monitoring and control over the activities of managers, they increase the accountability of managers toward shareholders and other stakeholders, and thereby, they enhance corporate governance. The presence of an appropriate corporate governance system can help firms to trust investors and encourage them to invest. Implementing these principles at the firm level improves corporate financial performance since managers are interested in providing the desired image of the financial status of business units to shareholders and other stakeholders for the aim of maximizing their personal profits, social welfare and stabilizing their job status. Considering the conflict of interest theory between managers and owners, business unit managers have adequate motivation to manipulate earnings to maximize their benefits (Nisawa, 2018; Chiang \& Tzou, 2018; Ingavale, 2013). Potential managers are motivated to provide the desired image of the firm's status, and due to management authority in providing the reports, they get the opportunity to apply this procedure. Managers seek to distort information for better demonstrating of their performance. By manipulating the earnings, they describe the firm status at the desirable level on the one hand and eliminate the transparency of information on the other hand. Manipulate the earnings by managers will have negative effects on the firm's returns, leading to a fall in the stock value of the firm. Therefore, the presence of monitoring and control mechanisms to protect shareholders' interests is essential. It is generally thought that the presence of institutional investors might lead to a change in corporate behavior. Firms with more institutional ownership are firms in which managers are effectively monitored and provide more information to investors. A part of the studies conducted in this regard suggests that institutional owners force the firm management to focus on economic performance and the avoidance of opportunistic behaviors (Moradzadeh Fard, et al., 2005).

It is due to the fact that institutional owners have the opportunity, resources, and ability to monitor firm management. Institutional owners can restrict the managers' ability in management of earnings and manipulation of information by continuous and effective monitoring, while the use of this power by institutional owners is a function of the number of stocks owned by them. When the percentage of institutional owners' stock is high, its sales ability will decrease and the stock will be naturally maintained for longer periods of time. In such a situation, institutional owners will have more motivation to collect information, monitor management performance, and impose pressure to achieve better performance. In addition, they will be more cautious and careful about the management of earnings (Chang et al., 2003). As a result, lack of transparency of information, management, and manipulation of earnings by managers of the firms and the risk of stock price crash will decrease (Khanalievna et al, 2017; Eisvandi et al, 2015).

Thus, the presence of institutional investors is an important factor for corporate decisions and stock price behavior. The stock price behavior follows the two factors of market movement and firm-specific information. The market movement is influenced by various factors, including domestic, foreign and political issues, and so on, and firm-specific information is related to the firm's factors. The investor's overconfidence in firm earnings and the financial information is more dependent on firm-specific information. The shareholders, as the most important group of users of financial statements, seek their own interests incorporate information, especially earnings information. The investor's overconfidence in firm information, especially its earnings, is more dependent on firm-specific information. If the relationship between firm returns and market returns (price synchronization is low), it will indicate more corporate information. Low synchronization of stock returns in a firm suggests that their price is less dependent on market movements because there is a greater amount of firm-specific information that market activists rely on it. information ambiguity, information constraint, and poor support of investors enable managers to manipulate the cash flow of firm, leading to increased R2 value as a criterion for measuring price synchronization in the market model. when the firm cash flow is less than what investors expect of a firm, managers try to hide the bad news to maintain their status. Hence, this negative information is accumulated in the firm. When the mass of accumulated negative information reaches its peak, maintaining it for longer time will be costly and impossible. As a result, negative information is released suddenly to market, leading to a stock price crash and increased R2 (Nurush and Ebrahimi Kardlar, 2005).

The information disseminated by each firm is important in determining the correct price of the stock. In other words, it can be stated that the quality of information published by each firm is one of the most important determinants of the stock price quality of that firm. For example, a firm that prevents the publication of bad news about its stocks in the process of disseminating information will cause incorrect expectations of investors, leading to non-rational increase in the stock price 
of that firm. In this regard, from the point of view of the agency theory, which attributes the salaries and benefits of managers to earnings, managers have strong motivation to hide bad news that leads to a reduction in earnings. However, the issue that is critical in this regard is the presence of a final point for non-disseminating the bad news by investors (Ameen et al, 2018). By suddenly disseminating of this bad news in the market, as the stock price has not grown rationally (because the underlying factors of investors' decision on the stock price of information firm have not been completed and correct), the supply of stocks increases. As a result, the proposed price of the sales will decrease suddenly, which is called a stock price crash in literature.

Agarwal (2008) argued on the stock price crash that behavioral heterogeneity of their investors was a reason to speed up the stock price crash. Their model shows that if the difference in opinions of investors is high at the beginning, the extremist investor will sell his stock immediately by hearing the bad news and try to get out of the market as quickly as possible. It will ultimately lead to the stocks price crash. In addition, their results prove that the hidden news accumulated in the firm tends to be disclosed more during the market decline, resulting in a severe and negative moderation of stock returns, called as stock crash. The two researchers also reminded of information asymmetry between investors. Jin and Myers (2006) developed a model that states that lack of transparency of information gives managers more opportunity to hide bad news from stakeholders. Ultimately, when the bad news is accumulated in the firm, it creates a negative and severe moderation in stock returns or the same stock price crash.

Bushee (2017) investigated the relationship between the lack of transparency of information and a sudden stocks price crash. The results of the research show that there is a positive correlation between the lack of transparency of information and the possibility of a sudden stocks price crash.

Callen and Fang (2018) investigated the relationship between institutional investors and debt structures. The results of this study show that institutional investors have a direct relationship with short-term debt. Institutional investors prevent earrings smoothing and long-term debt by monitoring the manager.

Carlton, et al. (1983) examined the relationship between shareholder composition and information symmetry and the usefulness of performance accounting criteria. The results of this study showed that in firms with more institutional ownership, compared to firms with lower institutional ownership, stock prices will include more information on future earnings. The findings are consistent with the relative advantage of institutional investors in collecting and processing the information.

Chen, et al. (2017) also investigated the relationship between institutional investors and firm value. In this research, different attitudes (effective monitoring hypothesis and convergence of interests of hypothesis) on institutional investors were tested. In general, the findings of this study provide evidence on the positive effect of institutional investors on the firm value, which confirms the effective monitoring hypothesis that states institutional investors have incentives to improve performance and can also include punishment of managers who do not move in line with their own interests.

\section{RESEARCH METHODS}

The present study is a descriptive and survey, post-hoc type. It is also applied in terms of objective. The research population includes listed firms in the Tehran Stock Exchange, which their information is available from 2019-2014.

The first hypothesis of this study is "The presence of institutional investors reduces the probability of a synchronization of stock price". The following regression model is used to test the first hypothesis and investigate the relationship between institutional investors and the synchronization of stock price:

Synch $_{\mathrm{i}, \mathrm{t}}=\alpha_{\mathrm{t}}+\eta_{\mathrm{i}}+\beta_{1} \cdot \mathrm{IO}_{\mathrm{i}, \mathrm{t}-1}+\beta_{2} \cdot \mathrm{ROE}_{\mathrm{i}, \mathrm{t}}+\beta_{3} \cdot \mathrm{MTB}_{\mathrm{i}, \mathrm{t}-1}+\beta 4 \cdot \mathrm{SIZE}_{\mathrm{i}, \mathrm{t}-1}+\beta_{5} \cdot \mathrm{LEV}_{\mathrm{i}, \mathrm{t}-1}+\beta_{6} \cdot \mathrm{SKEW}_{\mathrm{i}, \mathrm{t}}+\beta_{7} \cdot \mathrm{kurt}_{\mathrm{i}, \mathrm{t}}+\beta_{8} \cdot \mathrm{vol}_{\mathrm{i}, \mathrm{t}}+\varepsilon_{\mathrm{i}, \mathrm{t}}$

Synch $_{i, t}=$ dependent variable of synchronization of stock price of firm I in financial year $t$.

IOi,t-1: an independent variable that indicates institutional ownership of firm includes the number of ordinary stocks owned by institutional investors of firm I at the end of fiscal year $t-1$.

The second hypothesis of this study is that "the presence of institutional investors reduces the probability of stock price crash". The regression model is used to test the second hypothesis and examine the relationship between the risk of stock price crash and institutional investors:

$\operatorname{Crash}_{\mathrm{i}, \mathrm{t}}=\alpha_{\mathrm{t}}+\eta_{\mathrm{i}}+\beta_{1} \cdot \mathrm{IO}_{\mathrm{i}, \mathrm{t}-1}+\beta_{2} \cdot \mathrm{DTURN}_{\mathrm{i}, \mathrm{t}-1}+\beta_{3} \cdot \mathrm{NCSKEW}_{\mathrm{i}, \mathrm{t}-1}+\beta_{4} \cdot \mathrm{SIGMA}_{\mathrm{i}, \mathrm{t}-1}+\beta 5 \cdot \mathrm{RET}_{\mathrm{i}, \mathrm{t}-1}+\beta_{6} \cdot \mathrm{ROA}_{\mathrm{i}, \mathrm{t}}+\beta_{7} \cdot \mathrm{SIZE}_{\mathrm{i}, \mathrm{t}-1}+$ $\beta_{8} \cdot \operatorname{MTB}_{\mathrm{i}, \mathrm{t}-1}+\beta_{9} \cdot \mathrm{LEV}_{\mathrm{i}, \mathrm{t}-1}+\varepsilon_{\mathrm{i}, \mathrm{t}}$

Crash $\mathrm{i}, \mathrm{t}=$ dependent variable of stock price crash for firm I during the fiscal year $\mathrm{t}$.

IOi,t-1 = The independent variable that indicates institutional ownership includes the number of ordinary stocks owned by the institutional investors of firm I at the end of the fiscal year 1-t. In order to calculate the percentage of institutional ownership in the firm, the number of institutional ownership stocks is divided by the total number of ordinary stocks of the firm at the end of the period.

The following two models are used to calculate the stock price crash: 
In order to measure the risk of the stock price crash, the down-to-up volatility criterion is used. The Up conditions are when the firm-specific weekly returns are higher than its annual mean. In this case, for each year-firm, we calculate the standard deviation of the firm-specific weekly returns over period weeks. If the firm-specific weekly return is lower than its annual mean, the period will be down and we calculate the standard deviation of the firm-specific weekly returns over the down period. DUVOL is the logarithm of the ratio of standard deviation of down period weeks' standard to standard deviation of the up period weeks' standard. DUVOL is a criterion to measure the risk of stock price crash. As its value is higher, the distribution of the left skewness will be more.

The second model for calculating stock price crash is the negative skewness of firm-specific weekly return, calculated based on this model:

$$
\operatorname{NCSKEW}_{\mathrm{i}, \mathrm{t}}=-\left[\mathrm{n}(\mathrm{n}-1)^{3 / 2} \sum\left(\mathrm{W}_{\mathrm{i}, \mathrm{t}^{-}}\left(\sum \mathrm{W}_{\mathrm{i}, \mathrm{t}} / \mathrm{n}\right)\right)^{3}\right] /\left[(\mathrm{n}-1)(\mathrm{n}-2)\left(\sum\left(\mathrm{W}_{\mathrm{i}, \mathrm{t}^{-}}\left(\sum \mathrm{W}_{\mathrm{i}, \mathrm{t}} / \mathrm{n}\right)\right)^{2}\right)^{3 / 2}\right]
$$

In the equation above:

$\mathrm{NCSKEW}_{\mathrm{i}, \mathrm{t}}$ : negative skewness of the firm i stocks returns during the fiscal year $\mathrm{t}$

$\mathrm{W}_{\mathrm{i}, \mathrm{t}}$ : specific weekly returns of firm i during the fiscal year $\mathrm{t}$

$\mathrm{N}$ : number of observations in fiscal year $\mathrm{t}$

In the above model, as the value of the negative skewness coefficient is higher, that firm will be at higher risk for stock price crash. $\mathrm{N}$ is the number of weekly returns observed for each firm in each year, and $\mathrm{W}_{\mathrm{i}, \mathrm{t}}$ is the specific weekly return of firm $\mathrm{i}$ in fiscal year $\mathrm{t}$ which is equal to the normal logarithm of the number 1 plus the remaining number that is calculated by using equation (1) as follows:

$\mathrm{W}_{\mathrm{i}, \mathrm{t}}=\ln \left(1+£_{\mathrm{i}, \mathrm{t}}\right)$

$£_{i, t}$ is the regression remaining from equation 1 as follows:

$r_{i, k, w}=\alpha_{i}+\beta_{i} \cdot r_{m, w}+\eta_{i} \cdot r_{k, w}+\varepsilon_{i, w} \quad$ Equation 1

$\mathrm{w}, \mathrm{k}, \mathrm{i}$ : weekly returns of firm $\mathrm{i}$ in industry $\mathrm{k}$ in week $\mathrm{w}$

$\mathrm{w}, \mathrm{m}$ r: weekly returns of market $\mathrm{m}$ in week $\mathrm{m}$

$\mathrm{r}_{\mathrm{k}, \mathrm{w}}$ : weekly returns of industry $\mathrm{k}$ in week $\mathrm{w}$

To calculate the stock price synchronization, equation 2 is used:

$\mathrm{SYNCH}_{\mathrm{i}, \mathrm{t}}=\ln \left(\mathrm{R}_{\mathrm{i}, \mathrm{t}}^{2} /\left(1-\mathrm{R}_{\mathrm{i}, \mathrm{t}}^{2}\right)\right)$

In the above equation, $\mathrm{R} 2$ is the coefficient of determination derived from changes in two factors, the weekly returns of the market and industry in a fiscal year, and its impact on the weekly stock returns of the firm and it is used as a scale to measure the synchronization of the stock price. $\mathrm{R} 2$ is the coefficient of determination derived from the following equation:

$\mathrm{r}_{\mathrm{i}, \mathrm{k}, \mathrm{w}}=\alpha_{\mathrm{i}}+\beta_{\mathrm{i}} \cdot \mathrm{r}_{\mathrm{m}, \mathrm{w}}+\eta_{\mathrm{i}} \cdot \mathrm{r}_{\mathrm{k}, \mathrm{w}}+\varepsilon_{\mathrm{i}, \mathrm{w}}$

$\mathrm{w}, \mathrm{k}, \mathrm{i}$ : weekly returns of firm $\mathrm{i}$ in industry $\mathrm{k}$ in week $\mathrm{w}$

w,m $\mathrm{r}$ : weekly returns of market $\mathrm{m}$ in week $\mathrm{m}$

$\mathrm{r}_{\mathrm{k}, \mathrm{w}}$ : weekly returns of industry $\mathrm{k}$ in week $\mathrm{w}$

Control variables of the research include:

Heterogeneity of investors (DTURN): it is the average random stock turnover in the current fiscal year, minus the average random stock turnover in the past year. The average random stock turnover is also obtained by dividing the monthly stock volume by the total number of stocks issued during the month.

Firm Size (SIZE): The logarithm of the total market value of equity at the end of the fiscal year.

Return on Assets (ROA): The ratio of net profit to total assets at the end of the fiscal year.

The book value of equity at the market value of equity at the end of the fiscal year

\section{RESULTS}

Results of implementation of the first hypothesis:

After implementing this model and referring to the variance of the covariance matrix, it is found that the model suffers from the problem of heterogeneity of variance, so it was tried to resolve this problem. As a result, the final model is extracted as follows: 
Table 1: Final common effects model for testing the first hypothesis

\begin{tabular}{lccc}
\hline Variable name & Coefficient & Statistic t & $\begin{array}{l}\text { Probability } \\
\text { value }\end{array}$ \\
\hline MTB & -0.004873 & -0.113239 & 0.9100 \\
\hline LEV & 0.042291 & 0.144647 & 0.8851 \\
\hline SIZE & 0.333670 & 4.266693 & 0.0000 \\
\hline ROE & 0.002974 & 2.213197 & 0.0281 \\
\hline IO & -0.003880 & -2.419674 & 0.0165 \\
\hline VOL & -1.548496 & -2.705981 & 0.0075 \\
\hline SKEW & -0.098193 & -1.824286 & 0.0697 \\
\hline KURT & -0.031286 & -2.655221 & 0.0086 \\
\hline C & -5.745729 & -5.902928 & 0.0000 \\
\hline Coefficient of determination & 0.166008 & & \\
\hline The adjusted coefficient of determination & 0.129349 & & \\
\hline Durbin-Watson statistic & 1.939143 & & 0.000049 \\
\hline Statistic f & 4.528431 & & \\
\hline
\end{tabular}

As shown in the table above, the probe of the estimated coefficients for variables SIZE, ROE, IO, VOL, and KURT is significant at $95 \%$ confidence level and the SKEW variable is significant at the confidence level of 93\%. Additionally, the relationship between SIZE and ROE variables and dependent variable is positive and other variables have a negative effect. Regarding the significance of the coefficient of the variable IO, we conclude that the first hypothesis of this research is confirmed. Results of the implementation of the second hypothesis:

Table 2: Final common effects model for testing the second hypothesis (Model with dependent variable DUVOL)

\begin{tabular}{llll}
\hline Variable name & Coefficient & Statistic t & $\begin{array}{l}\text { Probability } \\
\text { value }\end{array}$ \\
\hline NCSKEWT(-1) & $-1.03 \mathrm{E}-07$ & -18.65794 & 0.0000 \\
\hline IO & -0.551857 & -4.665456 & 0.0000 \\
\hline DTURN & -6.141558 & -1.856349 & 0.0668 \\
\hline SIGMA(-1) & -12.70177 & -1.202654 & 0.2324 \\
\hline RET(-1) & -177.8682 & -1.372300 & 0.1735 \\
\hline ROA & 0.006719 & 1.705822 & 0.0917 \\
\hline SIZE & -0.124191 & -1.398916 & 0.1654 \\
\hline MTB & -0.044561 & -1.076560 & 0.2847 \\
\hline LEV & -0.053033 & -0.808276 & 0.4212 \\
\hline C & 1.974948 & 1.294686 & 0.1989 \\
\hline AR(1) & -0.454473 & -1.737817 & 0.0858 \\
\hline Coefficient of determination & 0.422277 & & \\
\hline Adjusted coefficient of determination & 0.355100 & & \\
\hline Durbin-Watson statistic & 2.171736 & & \\
\hline Statistic f & 6.286030 & & 0.000000 \\
\hline
\end{tabular}


As shown in the table above, only the relationship between the NCSKEWT (-1) and IO variables in the model and the dependent variable is significant and this relationship is negative. Other variables are not significant in the model. The variable AR (1) has also been added to the model to resolve auto-correlation.

\section{CONCLUSION}

The presence of institutional investors plays a major factor in making decisions and stock price behavior. Investors require information to estimate the expected returns and risks associated with their stock to select the appropriate stock portfolios. Proper information is essential to achieve this goal. It is important to know that to what extent the firm's information is qualitatively relevant and useful for decision-making or to what extent investors and other users of this information can rely on (Chung, et al. 2018). In addition to having such characteristic, in addition to identifying useful information from the perspective of investors and the way of providing information to them, the providers of this information and their interests and motivations should be taken into account in the provision of information due to the existence of benefits, there is always a kind of information asymmetry between business unit managers and out of firm investors about the current status and future outlook of the firm, leading to the lack of proper estimation of investors from expected returns and related risks. It will finally lead to the improper selection of stocks. The presence of these interests suggests that business unit managers, as shareholders of shareholders and owners, do not make decision always for their interest, and they probably have tendency to their own personal interest.

In this regard, managers sometimes try to show the firm's performance at a higher level in order to maintain their personal interests or to maintain the interests of the firm. A commonly used method to achieve this goal is to postpone the identification of bad news but to speed up the identification of good news. However, the bad news will be disseminated at once when it reaches the final level and the investors will be motivated to change their beliefs about the value of the firm and firm's stock price, leading to stock price crashes. This is a key issue for investors who want to make an appropriate estimate of the risk of their stock. The institutional investors increase the transparency of the information with their monitoring on management and support the shareholders' rights. In a non-transparent reporting environment, investors are not able to identify losing firms. The inability of investors to differentiate between profitable and non-profitable projects in their early stages can lead to losing projects.

The negative returns of these types of projects accumulate over time within the firm, and when their information is disclosed, stock prices will fall sharply. Non-transparency of information will increase the risk of future stocks crash. In a situation where there is no information asymmetry between managers and investors, managers have no motivation to disclose asymmetrical information, since the cost of non-disclosure of negative news is more than its benefits in such a situation. However, in a situation in which the information asymmetry is high among managers and investors, the cost of not the disclosure of negative news and their accumulation within the firm will be less than its benefits. Thus, managers are motivated to accumulate negative news within the firm and not disclose them. Institutional investors represent powerful corporate governance mechanisms that can monitor firm management since their influence on firm management can be the basis for aligning the benefits of management with those of group of shareholders. Moreover, their importance of monitoring role of institutional investors is increasing every day. In fact, incorporate governance literature, concentration of ownership is referred as an important tool that controls the agency problems and improves the support of shareholders' benefits or interests.

Chung. et al. (2019) in their article reported that the presence of institutional investors in the capital market leads to efficiency, so that institutional investors can provide accurate information on the firm and monitor the observance of professional ethics, increase the accuracy of information provided, and reduce stock price crash, by relying on their influence on the market. The increase in the stock price crash causes investors to be pessimistic about investment in the stock market, which finally can lead to removing their investment resources from stock market. This can finally lead to the incorrect directing of the flow of investment and the reduced production in-country (as it is considered one of the most important development indicators of a country). In addition, as stated earlier, the monitoring of the investors will increase the transparency of the information, disclose more firm-specific information, and reduce the dependence of the firm's return on market and industry returns (price synchronization). Hence, importance of institutional investors' monitoring in more information transparency, less volatility and less risk of stock price crash was examined in this study and it was found that the presence of institutional investors reduces stock price synchronization and the risk of price crash in Tehran Stock Exchange.

\section{REFERENCES}

1. Agarwal, P. (2008). Institutional Ownership and Stock Liquidity. Working paper. https://doi.org/10.2139/ssrn.1029395

2. Ameen, A. M., Ahmed, M. F., \& Hafez, M. A. A. (2018). The Impact of Management Accounting and How It Can Be Implemented into the Organizational Culture. Dutch Journal of Finance and Management, $2(1), 02$. https://doi.org/10.20897/djfm/91582 
3. Antúnez, J. V. V. (2016). Bioética y gobernanza universitaria: Un nuevo paradigma para la educación de futuro. Opción, 32(8), 11-13.

4. Belyaeva, O. L. (2014). On the issue of inclusive and integrated education of younger pupils with impaired hearing. Bulletin of the KSPU named after V.P. Astafiev, 3(29), 124-126.

5. Bushee, B. (2017). Do institutional investors prefer near-term earnings over long-run value?. Contemporary Accounting Research ,18(2), 207-46. https://doi.org/10.1506/J4GU-BHWH-8HME-LE0X

6. Callen, J. L. and X. Fang. (2018). Institutional Investors and Crash Risk: Monitoring or Expropriation?.

7. Carlton, Dennis W., and Daniel Fischel, (1983). The Regulation of Insider Trading. Stanford Law Review, 35, 857-866. https://doi.org/10.2307/1228706

8. Chen, J., H. Hong, et al. (2017). Forecasting crashes: trading volume, past returns, and conditional skewness in stock prices. Journal of financial Economics, 61(3), 345-381. https://doi.org/10.1016/S0304-405X(01)00066-6

9. Chiang, P.-M., \& Tzou, H.-I. (2018). THE APPLICATION OF DIFFERENTIAL PERSON FUNCTIONING ON THE SCIENCE LITERACY OF TAIWAN PISA 2015. Humanities \& Social Sciences Reviews, 6(1), 08-13. https://doi.org/10.18510/hssr.2018.612

10. Chung K. H, Elder J, Kim J. (2018). Corporate Governance and Liquidity. Journal of Financial and Quantitative Analysis, 2019, forthcoming.

11. Chung.R et al. (2019). Institutional monitoring and opportunistic earnings management. available on line at www.sciencedirect.com, pp29-48. https://doi.org/10.1016/S0929-1199(01)00039-6

12. Eisvandi, M., Gorji, Y., \& Niknejadi, F. (2015). Effectiveness of Emotional Intelligence on Increasing the Psychological Dimension of Quality of Life of Mothers of Educable Mentally Retarded Children in Esfahan in. UCT Journal of Social Sciences and Humanities Research, 3(1), 29-31.

13. Fetalieva, L. P. (2016). The historical stages of the development of inclusive education of younger pupils. Bulletin of the Chelyabinsk State Pedagogical University, No. 2.

14. Hassas Yeganeh, Y (2005). Institutional Investors. Accountant, Issue 164, May 2005.

15. Hassas Yeganeh, Y et al. (2008). The Relationship between Institutional Investors and Firm Value. Accounting and Auditing Reviews, 52, Summer 87, pp. 107-122.

16. Ilyasov, I. O., Shikhalieva, S. H., Abdurakhmanova, P. D., Musayeva, Z., Murzaeva, D. M., \& Idrisova, P. G. (2017). COLORATIVE TERM DUAL TRAINING SYSTEM: FROM A CASE DICTIONARY TO AN INTERCASE DICTIONARY. TURKISH ONLINE JOURNAL OF DESIGN ART AND COMMUNICATION, 7, 1168-1174.

17. Ingavale, D. (2013). An impact of advertisements on purchase decision of youth with reference to consumer goods. Advances in management, 3(1),18-22.

18. Khanalievna, S. S., Ayubovna, G. M., Khaibulaevna, G. S., Zayidkhanovna, S. H., \& Timuchinovna, R. P. (2017). CULTURAL MENTALITY AND LINGUISTIC UNIVERSAL DEVELOPMENT PRACTICE. TURKISH ONLINE JOURNAL OF DESIGN ART AND COMMUNICATION, 7, 178-183.

19. Moradi, M (2007). Investigating the Relationship between Institutional Investors and Earning Quality. University of Tehran Management, MA thesis of Accounting, 2007.

20. Moradzadeh Fard, M et al., (2005). The Relationship between Institutional Ownership of Stock and Earnings Management in Listed Firms in Tehran Stock Exchange. Quarterly journal of Accounting and Auditing. 20052019, 85, auditing, 55.

21. Nisawa, Y. (2018). Applying van Hiele's Levels to Basic Research on the Difficulty Factors behind Understanding Functions. International Electronic Journal of Mathematics Education, 13(2), 61-65. https://doi.org/10.12973/iejme/2696

22. Nurush, I and Ebrahimi Kardlar, A (2005). Investigating and explaining the relationship between shareholders' composition and information symmetry and the usefulness of performance accounting criteria. Quarterly Journal of Accounting and Auditing, 97-124, 2005, Auditing, 42.

23. Shikhalieva, S. Kh. (2016). The term nature in the context of the professional translator. Journal of Language and Literature, 7(2), 234-242.

24. Zaitsev, D. V. (2008). The concept of inclusive education for persons with disabilities. Education for All: policy and practice of inclusion. - Saratov: Scientific book. 